\title{
Verifikasi Golongan Darah Manusia Berbasis Citra Dijital Menggunakan Logika Fuzzy
}

\author{
Arief Bramanto Wicaksono Putra ${ }^{1^{*}}$, Didi Susilo Budi Utomo ${ }^{2}$, M Dicky Rahmawan ${ }^{3}$ \\ ${ }^{1,2,3}$ Prodi Teknik Informatika Politeknik Negeri Samarinda,Kampus Gunung Lipan,Samarinda \\ "E-mail: ariefbram@gmail.com
}

\begin{abstract}
Biometrics system is a self-recognition technology using human body parts or human behavior, to improve efficiency and effectiveness in faithful aspects of life by reducing the use of identity cards and passwords. It takes a system that can help humans to recognize the type of blood type. introduction type blood type can be done one of the computer with pattern recognition method and training each characteristic blood group through image. The experiment in this study discusses the verification of human blood group that begins with data collection, image acquisition, preprocessing, feature extraction. From human blood cells that later could form a special pattern of the collection of characteristic extraction results. By using the combination of euclidean distance and correlation coefficient method, the pattern of training result using fuzzy linguistic value is in low medium and medium range. Using 20 test data in which each blood group consisted of 5 samples, the result of the verification of matches tested using False Acceptance Rate (FAR) and False Rejected Rate (FRR) was $45 \%$ with Accuracy (Acc) equal to $83 \%$
\end{abstract}

Keywords: verification, euclidean distance, correlation coefficient, FAR, FRR, accuracy

\begin{abstract}
ABSTRAK
Sistem biometrika merupakan teknologi pengenalan diri dengan menggunakan bagian tubuh manusia ataupun dari perilaku manusia, untuk meningkatkan efisiensi dan efektifitas dalam setia aspek kehidupan dengan mengurangi pemakaian kartu identitas dan kata sandi. Diperlukan sebuah sistem yang dapat membantu manusia untuk mengenali tipe golongan darah. pengenalan tipe golongan darah dapat dilakukan computer salah satunya dengan metode pengenalan pola dan pelatihan masing masing karakterristik golongan darah melalui citra.Percobaan pada penelitian ini membahas tentang verifikasi golongan darah manusia yang diawali dengan pengumpulan data, akusisi citra, preprocessing, ekstraksi ciri. dari sel darah manusia yang nantinya dapat membentuk suatu pola khusus dari kumpulan hasil ekstraksi ciri. Dengan menggunakan kombinasi metode euclidean distance dan correlation coefficient diperoleh pola hasil pelatihan yang menggunakan fuzzy linguistic value berada pada rentang low medium dan medium. Dengan menggunakan 20 data uji dimana setiap golongan darah terdiri dari 5 sampel, diperoleh keputusan hasil verifikasi kecocokan yang diuji dengan menggunakan metode unjuk kerja False Acceptance Rate (FAR) sebesar dan False Rejected Rate (FRR) sebesar 45\% dengan tingkat Akurasi (Acc) sebesar 83\%
\end{abstract}

Kata kunci: verifikasi, euclidean distance, correlation coefficient, FAR, FRR, akurasi

\section{PENDAHULUAN}

Darah merupakan salah satu bagian penting dalam tubuh. Darah dibedakan menjadi beberapa golongan yaitu A, B, O, dan AB. Secara konvensional, mendeteksi golongan darah dengan cara meneteskan serum anti-A dan serum anti-B ke darah yang akan dikenali kemudian melakukan pengamatan langsung terhadap reaksi tetesan serum tersebut. Secara komputerisasi, golongan darah dapat dikenali melalui pola dari citra darah yang telah telah ditetesi serum anti A dan anti B. Setelah melalui beberapa tahap pengolahan citra, sistem akan melakukan proses klasifikasi untuk menentukan jenis golongan darah dari citra darah tersebut [1]. Oktari,A dkk [2] melakukan pemeriksaan golongan darah ABO dilakukan untuk menentukan jenis golongan darah pada manusia. Penentuan golongan darah ABO pada umumnya dengan menggunakan metode slide. Metode ini didasarkan pada prinsip reaksi antara aglutinogen (antigen) pada permukaan eritrosit dengan aglutinin yang terdapat dalam serum atau plasma yang membentuk aglutinasi atau gumpalan.

Biometrika menawarkan sistem pengenalan yang lebih dapat dipercaya atau lebih handal, biometrika tidak mungkin dilupakan, tidak mudah hilang, tidak dapat digunakan secara bersama-sama, dan sulit untuk diduplikasi. Kelebihan-kelebihan inilah yang menyebabkan biometrika banyak digunakan untuk sistem pengenalan seseorang secara 
otomatis baik untuk sistem identifikasi maupun verifikasi. Pengenalan pola dalam identifikasi biometrik membutuhkan metode pengenalan yang akurat agar tidak terjadi kesalahan dalam identifikasi. Masing-masing biometrik tidak tidak dapat diterapkan metode pengenalan yang sama dalam hal mencari keakuratan tertinggi, hal ini dikarenakan setiap ciri biometrik adalah unik dan diperlukan pendekatan yang berbeda untuk masing-masing ciri biometrik.Penelitian dengan perspektif analisis dari pemilihantahap pra proses, perspektif analisis dari metode ekstraksi fitur dan dari perspektif penggunaan metode klasifikasi yang tepat untuk mencari kelompok yang paling sama antara input dan basis data [3].

Pada proses pengenalan pola meliputi: pengumpulan data, ekstraksi ciri data, klasifikasi data dan verifikasi data. Metode kecerdasan buatan berperan pada klasifikasi dan verifikasi data. Salah satu metode kecerdasan buatan yang akan digunakan adalah metode fuzzy logic (logika samar). Metode yang digunakan dalam tugas akhir ini adalah metode fuzzy logic, karena metode fuzzy logic sangat efektif untuk menjelaskan faktor-faktor ketidakpastian yang tingkat frekuensi kemunculannya cukup tinggi dalam proses mengidentifikasi suatu objek di citra. Dengan metode fuzzy, faktor-faktor ketidakpastian dalam menentukan jenis objek dapat diperhitungkan sehingga dapat mengurangi kesalahan dalam menentukan suatu objek [4]

Pengolahan citra dan verifikasi pola merupakan bagian dari computer vision. Pengolahan citra merupakan suatu teknik pengolahan gambar untuk memperoleh suatu output yang dibutuhkan sedangkan verifikasi pola merupakan proses untuk pencocokan pola satu dengan pola lain. Teknik-teknik dalam pengolahan citra dan verifikasi pola memainkan peranan penting pada verifikasi pola golongan darah manusia sebagai bagian keilmuan biometrik dimana manusia yang dijadikan objek verifikasi. Verifikasi golongan darah manusia merupakan salah satu teknologi biometrika yang menjadi pusat perhatian para peneliti. [5]

Berdasarkan acuan penelitian yang berkaitan tentang verifikasi pola, percobaan pada penelitian ini membahas tentang verifikasi golongan darah manusia yang diawali dengan pengumpulan data, akusisi citra, pre processing, ekstraksi ciri. dari sel darah manusia yang nantinya dapat membentuk suatu pola khusus dari kumpulan hasil ekstraksi ciri. Hasil yang diharapkan adalah sebuah keputusan untuk melakukan verifikasi kecocokan yang diuji dengan menggunakan metode unjuk kerja False Acceptance Rate dan False Rejected Rate sebagai pengukuran tingkat keberhasilan atau biasa disebut uji performansi.

Ruang lingkup pengolahan citra dan model pengenalan pola berbasis statistik merupakan landasan deduktif dalam membangun sebuah kerangka konsep penelitian yang menjelaskan proses data empiris golongan darah maka dalam penelitian ini memilih hasil dari perubahan golongan darah yang telah diberi serum tertentu untuk kemudian diakuisisi menggunakan microscopes dan bantuan lensa dijital sebagai objek yang akan diamati dengan bentuk citra dijital. Penelitian secara eksperimen dengan kajian simulatif dilakukan pada pre processing, bagian ekstraksi fitur di tahapan image analysis dan keputusan berupa verifikasi. Terdapat beberapa konsep pada penelitian ini, yang terdiri dari konsep pengenalan pola sebagai suatu model dalam proses verifikasi pola dan konsep pengolahan citra sebagai suatu proses dalam transformasi citra hasil akuisisi menjadi citra siap saji yang bertujuan memperoleh ciri yang optimal. Kerangka Konsep penelitian ini disajikan dalam gambar 1.

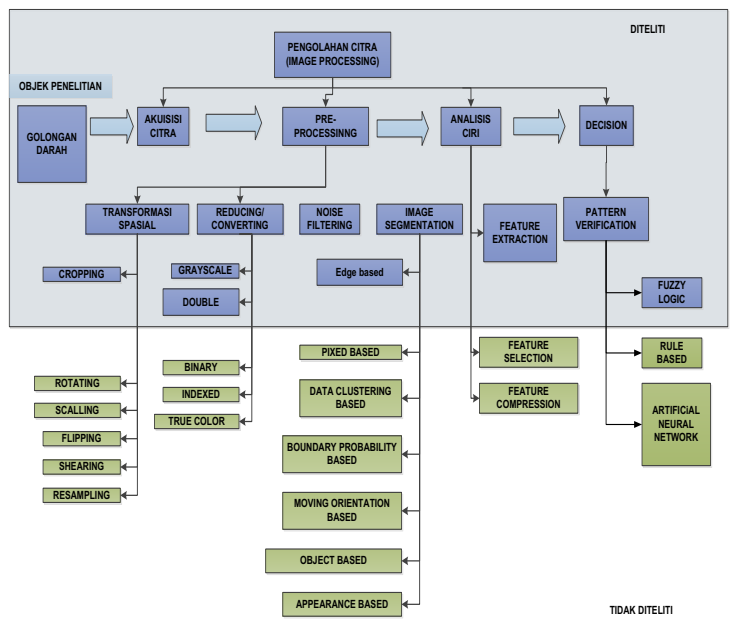

Gambar 1. Kerangka Konsep Penelitian

\section{METODE PENELITIAN}

Data mentah berasal dari data yang diambil menggunakan microscopes analog dengan pengaturan yang sama, dengan sampel darah yang diperoleh dari sebuah laboratorium rumah sakit di kota samarinda.Dengan bantuan digital akuisitor data dari microscopes analog dirubah menjadi citra dijital dengan masing masing sampel darah yang telah terklasifikasi berdasarkan golongan darah dengan serum anti 
gen,dari jumlah data mentah yang diambil akan terpilih beberapa data relatif lebih baik.

Solusi masalah terdiri dari dua tahapan utama yaitu memperoleh ciri dari hasil ekstraksi dari masing masing golongan darah dan melakukan verifikasi pengujian dengan data citra darah yang baru sebagai proses validasi dimana tingkat keberhasilan atau performance acceptance akan diukur menggunakan metode FAR dan FRR. Tahapan diatas dibangun dalam bentuk flow diagram seperti ditunjukan pada gambar 2.

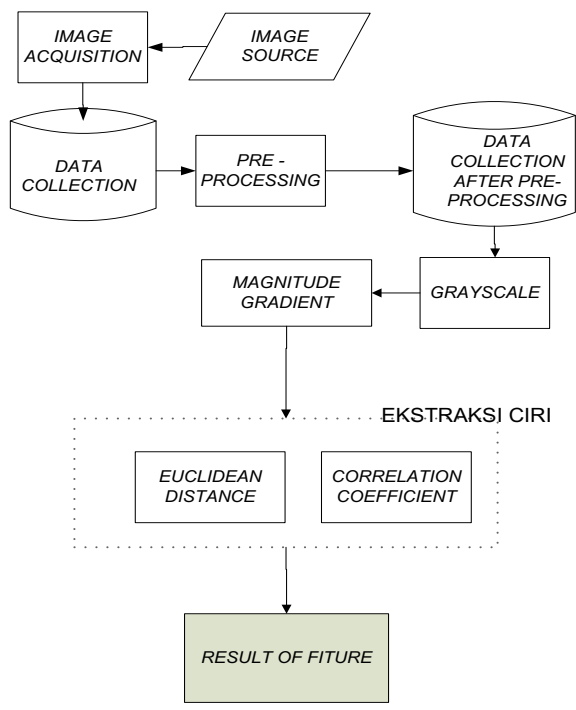

Gambar 2. Diagram Alir Penelitian

Citra yang berformat dijital (jpg) dikumpulkan dalam sebuah data collection berdasarkan kelas golongan darah. Selanjutnya data citra dijital tersebut akan melalui tahap pre processing yang terdiri dari [6] :

1. Pembacaan data dari raw data collection

2. Melakukan cropping (reduce pixel) untuk menghilangkan kesalahan informasi

3. Menghilangkan derau (noise filtering) dengan filter Gaussian

4. Melakukan color transformation dari RGB to grayscale

Pada tahap ekstrasi fitur, masing masing basis mengeluarkan fitur khusus yang berupa rata-rata Euclidean Distance dan ratarata Correlation Coefficient. Pengujian yang di gunakan untuk solusi verifikasi pada tahap keputusan menggunakan fuzzy rule based, menyerupai pada alur penelitian, dimana perbedaan dilakukan pada data image source yang sudah dibagi menjadi data pelatihan dan data pengujian sesuai dengan konsep pengenalan pola yang bisa diperjelas melalui gambar 3 .

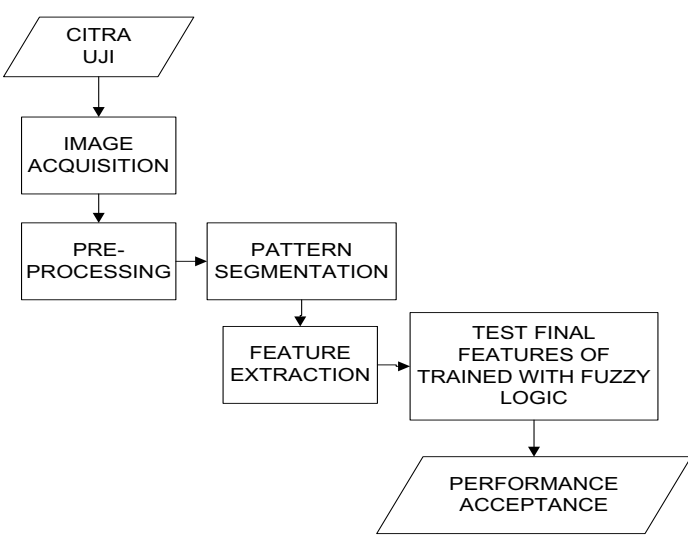

Gambar 3. Pengujian Citra Uji Dengan Fuzzy Logic

\section{HASIL DAN PEMBAHASAN}

\section{A. Akuisisi Dan Pre Processing}

Proses akuisisi citra adalah pemetaan suatu pandangan menjadi citra continu dengan menggunkan sensor. Metode akuisisi data yang dilakukan pada penelitian ini adalah menggunakan microscopes dan di cuplik menggunakan handphone yang hasilnya berupa citra dijital. Pada proses yang dilakukan akuisisi adalah sebagai berikut:

1. Mengumpulkan golongan darah a,b,o,ab sebanyak 24 sampel, dimana tiap golongan darah ada sebanyak 6 orang

2. Meneteskan anti a dan anti b agar memperoleh ciri citra golongan darah a, b, o, ab. Dan menaruh tiap tetes di atas cover glass

3. Format penyimpanan menggunakan (JPG)

4. Menggunakan perbesaran microscopes $40 \mathrm{x}$ perbesaran dan lensa kamera handphone 8 megapixel, resolusi 3264×2448 pixels 
Proses akuisisi dapat dimodelkan oleh gambar 4.



Gambar 4. Model Akuisisi Citra Darah

Pada penelitin ini jenis microscopes dan camera handphone ataupun lingkungannya tidak mempengaruhi analisis secara detail, keadan coverglass pada microscopes dan lensa microscopes yang bersih menjadi standarisasi yang di haruskan. Hasil cuplik dikumpulkan dalam sebuah data collection. Hasil dari akuisisi citra dapat dilihat pada gambar 5 .

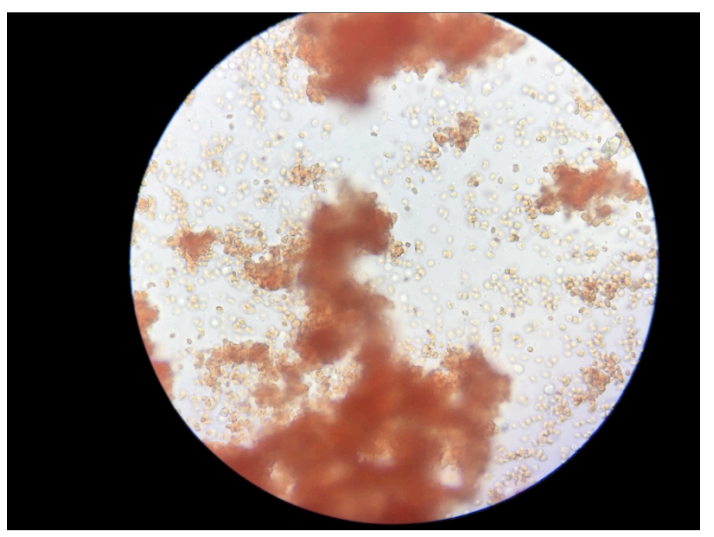

Gambar 5. Sampel Citra Dijital Darah

Data citra yang telah di diakuisisi diolah kedalam proses pre processing. Akan diambil 2 (dua) sampel yang terdiri dari citra yang memiliki seruma anti A dan citra yang memiliki serum anti B dari masing masing golongan darah untuk di ambil cirinya .Pada tahapan pre processing ini, hasil akuisisi akan diproses dengan menggunakan bantuan program komputasi dan aplikasi.
Proses pertama yaitu cropping, proses ini juga merupakan bagian yang paling penting untuk mendapatkan data citra yang maksimum dengan memotong tepi koordinat $\mathrm{X}$ dan $\mathrm{Y}$ pada image, yang hasilnya berupa pola citra yang mempunyai $\mathrm{X}$ dan $\mathrm{Y}$ yang maksimum. Proses pemotongan dengan imcroping. Dengan memilih nilai koordinat $\mathrm{x}$ (kiri atas) sebesar 270 dan 99, dan koordinat y (kanan bawah) sebesar 574 dan 518., penempatan frame ini menggunakan titik tengah sebagai acuan dalam menempatkan frame agar seluruh citra yang digunakan pada proses akuisisi nya menggunakan prosedur yang samauntuk mengurangi resiko terjadinya perbedaan hasil antara citra uji dan citra yang digunakan untuk pelatihan ciri, hasil terlihat pada gambar 6 .

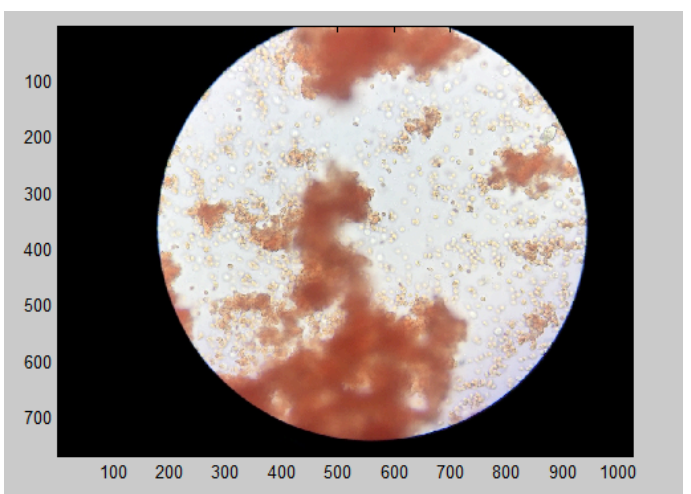

(a)

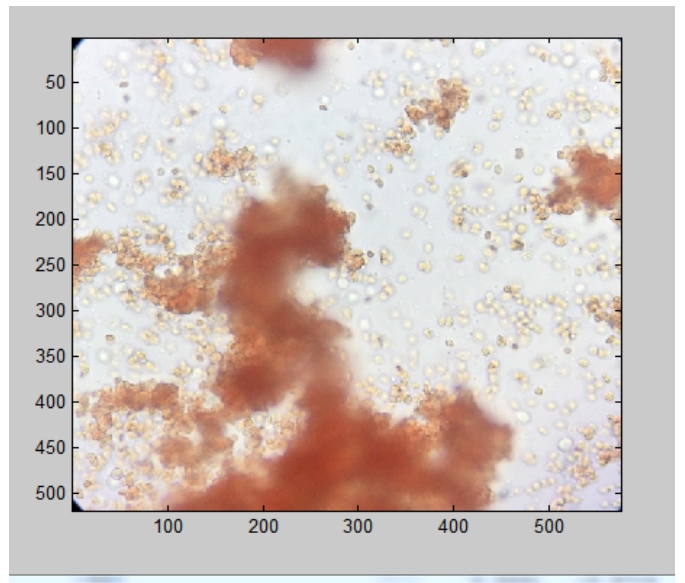

(b)

Gambar 6. Proses Cropping. (a) Citra sebelum dicropping (b) Citra hasil cropping

Tahap selanjutnya dari pre processing adalah menghilangkan noise. Filtering citra merupakan salah satu bagian dari perbaikan kualitas citra, yakni menghaluskan dan menghilangkan atau mereduksi noise yang ada pada citra. Konversi citra RGB ke grayscale 
bertujuan agar citra RGB yang tersusun dari 3 nilai yaitu red, green dan blue di konversi menjadi 1 nilai saja hal ini mempermudah dalam hal komputasi dan ekstraksi ciri. Penelitian ini digunakan fungsi magnitude gradient untuk membaca image dan mengembalikan gradien directional, $\mathrm{Gx}$ (Horizontal) dan Gy(vertical). Dengan menggunakan fungsi dari operator gradien sobel yaitu :

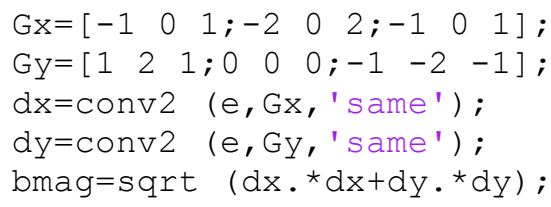

Data keluaran dari tahap pre processing dapat dilihat pada gambar 7 .

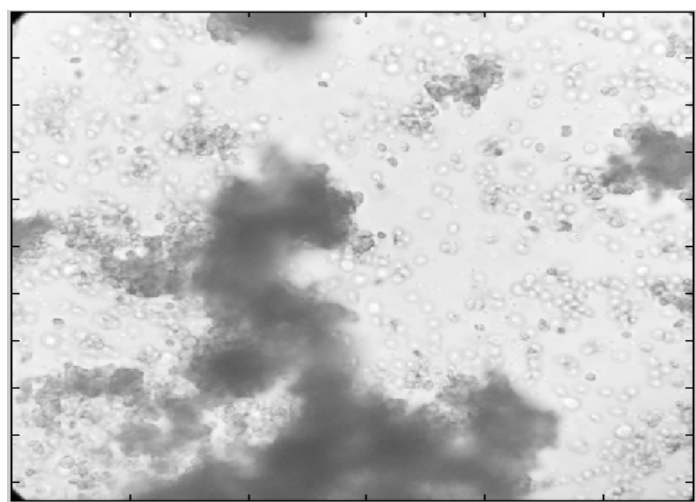

Gambar 7. Data Siap Saji Hasil Pre Processing

\section{B. Ekstraksi Ciri}

Ekstraksi ciri atau ekstraksi fitur merupakan bagian fundamental dari analisis citra. Menurut Putra, D [7], karakteristik fitur yang baik sebisa mungkin memenuhi persyaratan berikut :

1 Dapat membedakan suatu objek dengan yang lainnya

2 Memperhatikan kompleksitar komputasi dalam memperoleh fitur. Kompleksitas komputasi yang tinggi tentu akan menjadi beban tersendiri dalam menemukan suatu fitur.

3 Tidak terikat (independence) dalam arti bersifat invariant terhadap berbagai transformasi (rotasi, penskalaan, penggeseran, dan lain sebagainya).

4 Jumlahnya sedikit, karena fitur yang jumlahnya sedikit akan dapat menghemat waktu komputasi dan ruang penyimpanan untuk proses selanjutnya (proses pemanfaatan fitur)
Ekstraksi ciri dilakukan dengan dua cara yaitu dengan menghitung Euclidean Distance dan Correlation Coefficient

a. Euclidean Distance.

Euclidean Distance adalah metrika yang paling sering digunakan untuk menghitung kesamaan dua vektor. Euclidean distance menghitung akar dari kuadrat perbedaan dua vektor. Rumus dari Euclidean Distance :

$$
d_{i j}=\sqrt{\sum_{k=1}^{n}\left(x_{i j}-x_{j k}\right)^{2}}
$$

Pada proses ekstraksi ciri disini, semua objek citra yang sudah melalui pre processing dan segmentasi dihitung rata - rata baris dan kolom dari setiap piksel satu objek sehingga hanya ada satu nilai Euclidean distance untuk setiap citra untuk memperoleh nilai dari Euclidean Distance. Syntax untuk memperoleh nilai Euclidean Distance yang dikemudian disimpan pada variable ED seperti contoh :

$$
\text { ed=dist (bmag); }
$$

Pada syntax tersebut, dist merupakan fungsi dari Euclidean Distance yang tersedia pada MATLAB. Hasil yang ditunjukkan pada proses diatas adalah matriks berukuran 575 x 575 ditunjukkan pada gambar 8

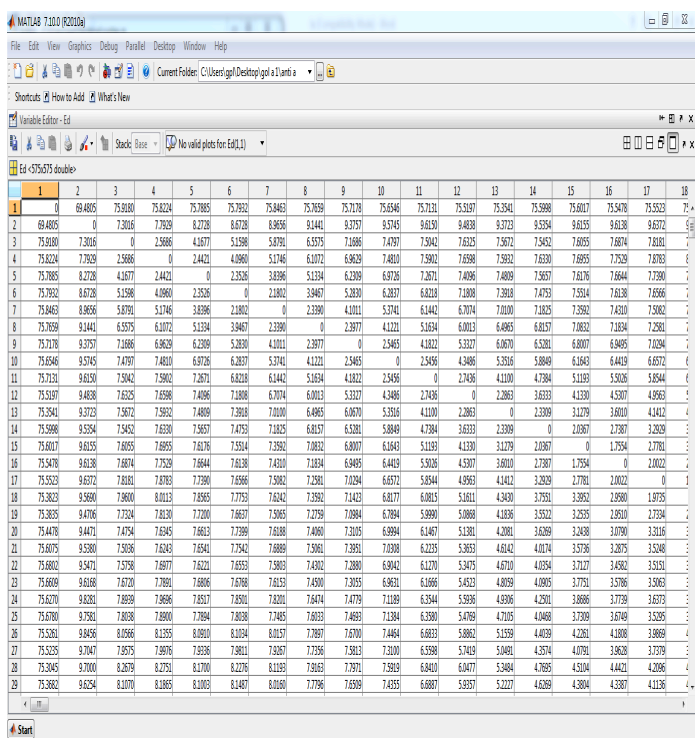

Gambar 8. Hasil Perhitungan Euclidean Distance Pada Sampel Citra

b. Correlation Coefficient.

Ekstraksi ciri menggunakan correlation coefficient pada penelitian ini adalah menghitung nilai kesamaan dibandingkan 
ketidaksamaan, hasil dari perhitungan tersebut akan dirata- rata berdasarkan baris dan kolom untuk merepresentasikan ciri pada citra menggunakan correlation coefficient. Rumus dari correlation coefficient :

$$
s_{i j}=\frac{\sum_{k=1}^{n}\left(x_{i k}-\overline{x_{l}}\right) \cdot\left(x_{j k}-\overline{x_{j}}\right)}{\left[\sum_{k=1}^{n}\left(x_{i k}-\overline{x_{l}}\right)^{2} \cdot \sum_{k=1}^{n}\left(x_{j k}-\overline{x_{j}}\right)^{2}\right]^{\frac{1}{2}}}
$$

Untuk memperoleh nilai dari Correlation Coefficient. Syntax untuk memperoleh nilai Correlation Coefficient yang kemudian disimpan pada variable $\mathrm{CC}$ seperti contoh :

$$
\mathrm{Cc}=\operatorname{corrcoef}(\text { bmag })
$$

Pada syntax tersebut, corrcoef merupakan fungsi dari Correlation Coefficient yang tersedia pada MATLAB. Hasil yang ditunjukkan pada proses diatas adalah matriks berukuran 575 x 575 ditunjukkan pada gambar 9.

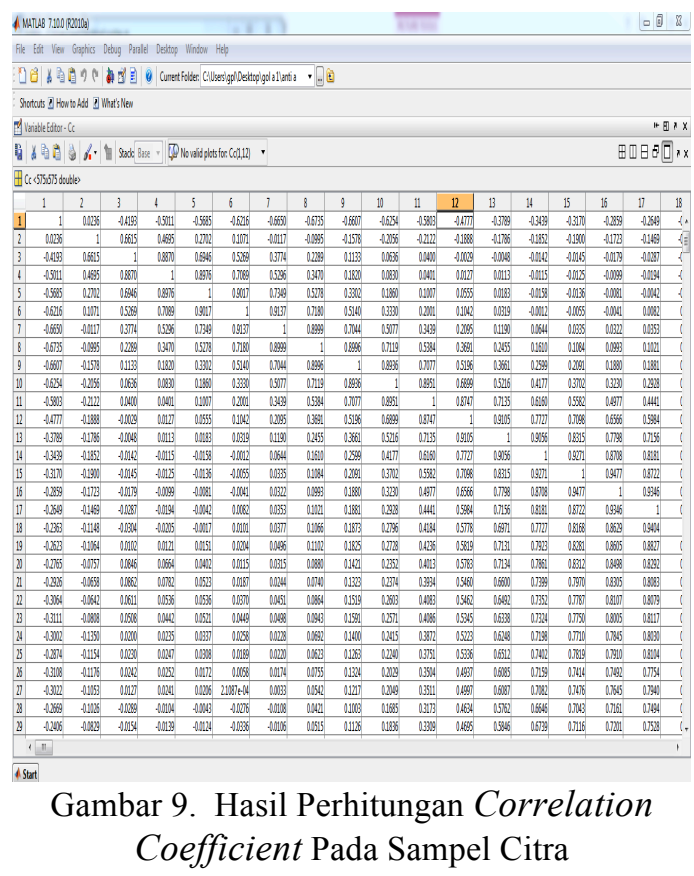

Dari sampel citra darah untuk proses pelatihan maka hasil ekstraksi ciri diambil dari nilai minimum dan maksimum dari setiap metode, yang dapat dilihat pada tabel 1 dan 2 . Untuk tabel 1 adalah ekstraksi ciri menggunakan metode euclidean distance, sedangkan tabel 2 adalah ekstraksi ciri menggunakan correlation coeefficient. Tujuan dari pengambilan nilai minimum maupun maksimum adalah untuk melihat seberapa besar irisan dari sampel citra antar golongan darah.
Tabel 1. Ekstraksi Ciri Citra Pelatihan Menggunakan Rata-Rata Euclidean Distance

\begin{tabular}{ccccc}
\hline \multirow{2}{*}{$\begin{array}{c}\text { Gol. } \\
\text { Darah }\end{array}$} & \multicolumn{2}{c}{ ANTI A } & \multicolumn{2}{c}{ ANTI B } \\
\cline { 2 - 5 } & $\min$ & Max & $\min$ & $\max$ \\
\hline $\mathrm{A}$ & 5.2653 & 6.8815 & 4.2897 & 5.0276 \\
\hline $\mathrm{AB}$ & 5.3076 & 6.5759 & 5.9438 & 7.6099 \\
\hline $\mathrm{O}$ & 4.0375 & 4.7767 & 4.4954 & 4.8759 \\
\hline $\mathrm{B}$ & 3.9742 & 4.5822 & 5.5176 & 5.9212 \\
\hline
\end{tabular}

Tabel 2. Ekstraksi Ciri Citra Pelatihan Menggunakan Rata-Rata Correlation Coefficient

\begin{tabular}{ccccc}
\hline \multirow{2}{*}{$\begin{array}{c}\text { Gol. } \\
\text { Darah }\end{array}$} & \multicolumn{2}{c}{ ANTI A } & \multicolumn{2}{c}{ ANTI B } \\
\cline { 2 - 5 } & $\min$ & Max & $\min$ & $\max$ \\
\hline $\mathrm{A}$ & 0.4258 & 0.5907 & 0.5438 & 0.7326 \\
\hline $\mathrm{AB}$ & 0.3597 & 0.6422 & 0.3621 & 0.5188 \\
\hline $\mathrm{O}$ & 0.6563 & 0.7585 & 0.5463 & 0.6103 \\
\hline $\mathrm{B}$ & 0.6646 & 0.7548 & 0.5356 & 0.5843 \\
\hline
\end{tabular}

Untuk merepresentasikan nilai minimal dan maksimal ciri pola golongan darah $\mathrm{A}, \mathrm{AB}$ dan $\mathrm{B}, \mathrm{O}$ berdasarkan positive dan negative anti $\mathrm{A}$ dan anti $\mathrm{B}$ menggunakan euclidean distance akan dibuat model visualisasi yang diperlihatkan pada gambar 10 .
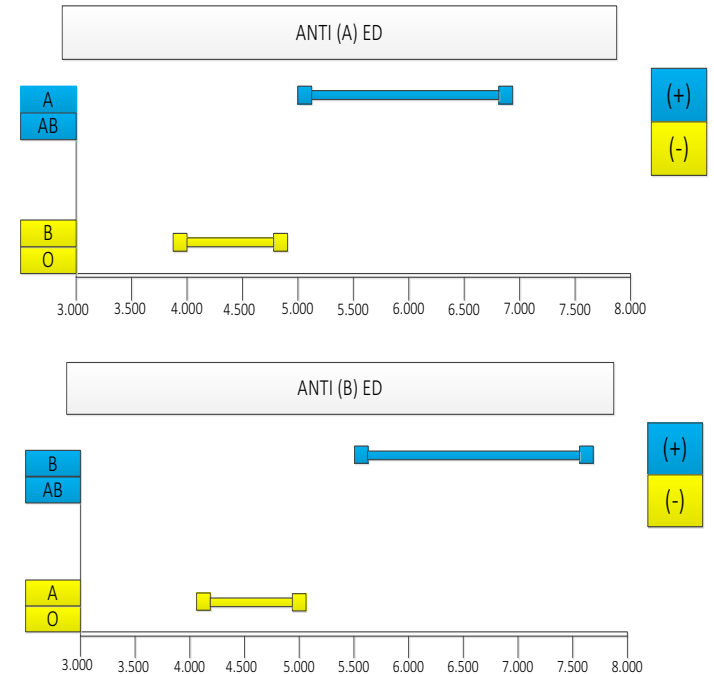

Gambar 10. Visualisasi Ekstraksi Ciri Euclidean Distance Citra Latih

Untuk merepresentasikan nilai minimal dan maksimal ciri pola golongan darah menggunakan Correlation Coefficient akan dibuat visualisasi yang diperlihatkan pada gambar 11 . 

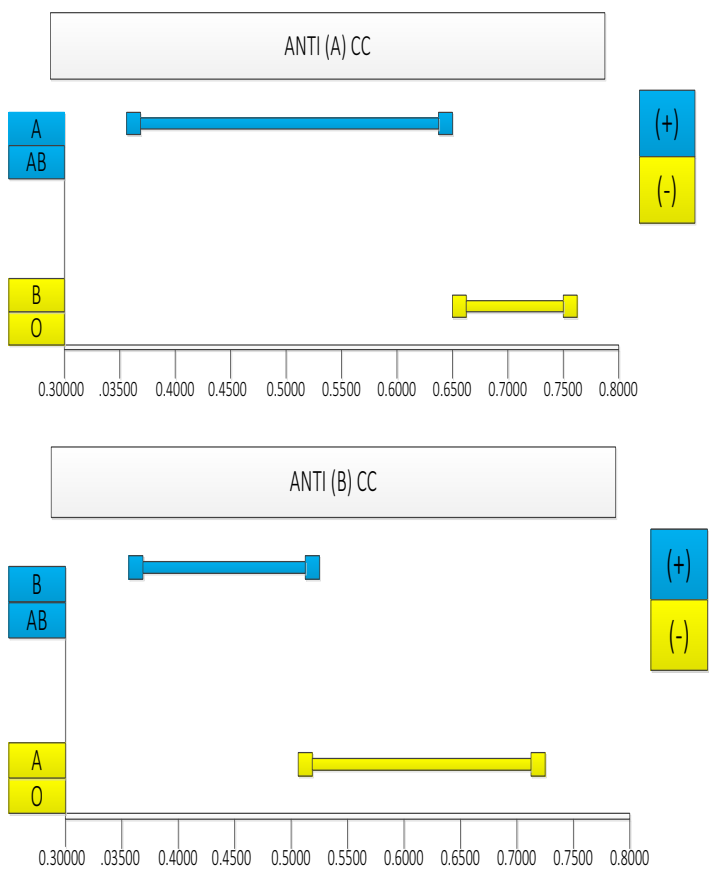

Gambar 11. Visualisasi Ekstraksi Ciri Correlation Coefficient Citra Latih

\section{Verifikasi Citra Menggunakan Fuzzy Logic}

Untuk melakukan proses verifikasi, ada beberapa tahapan yang harus disiapakan yaitu :

1. Menyiapkan data pengujian

2. Membangun Fuzzy Inference System (FIS) model Mamdani dengan 5 linguistic value

3. Membangun tabel kebenaran Golongan Darah berdasar data pelatihan dengan FIS

4. Melakukan verifikasi hasil FIS dari data uji terhadapa tabel kebenaran

Berikut ini dengan pengujian setiap golongan darah diperoleh 5 sampel, yang diberi serum anti A dan anti $\mathrm{B}$, sehingga total sampel citra uji adalah 20 sampel. Ekstraksi ciri data uji ditunjukan pada tabel 3 dan 4 .

Tabel 3. Ekstraksi Ciri Citra Uji Menggunakan RataRata Euclidean Distance

\begin{tabular}{ccc}
\hline $\begin{array}{c}\text { Golongan } \\
\text { Darah }\end{array}$ & ANTI A & ANTI B \\
\hline $\mathrm{A}_{1}$ & 6.881 & 5.027 \\
\hline $\mathrm{A}_{2}$ & 6.867 & 4.938 \\
\hline $\mathrm{A}_{3}$ & 5.265 & 4.871 \\
\hline $\mathrm{A}_{4}$ & 5.434 & 4.428 \\
\hline $\mathrm{A}_{5}$ & 5.933 & 4.632 \\
\hline $\mathrm{AB}_{1}$ & 5.307 & 5.943 \\
\hline
\end{tabular}

\begin{tabular}{ccc}
\hline $\mathrm{AB}_{2}$ & 5.413 & 6.331 \\
\hline $\mathrm{AB}_{3}$ & 5.477 & 6.403 \\
\hline $\mathrm{AB}_{4}$ & 6.518 & 7.609 \\
\hline $\mathrm{AB}_{5}$ & 6.575 & 7.490 \\
\hline $\mathrm{O}_{1}$ & 4.037 & 4.495 \\
\hline $\mathrm{O}_{2}$ & 4.159 & 4.547 \\
\hline $\mathrm{O}_{3}$ & 4.225 & 4.852 \\
\hline $\mathrm{O}_{4}$ & 4.601 & 4.846 \\
\hline $\mathrm{O}_{5}$ & 4.744 & 4.875 \\
\hline $\mathrm{B}_{1}$ & 3.974 & 5.517 \\
\hline $\mathrm{B}_{2}$ & 4.021 & 5.714 \\
\hline $\mathrm{B}_{3}$ & 4.233 & 5.645 \\
\hline $\mathrm{B}_{4}$ & 4.5822 & 5.910 \\
\hline $\mathrm{B}_{5}$ & 4.496 & 5.921 \\
\hline
\end{tabular}

Tabel 4. Ekstraksi Ciri Citra Uji Menggunakan RataRata Correlation Coefficient

\begin{tabular}{ccc}
\hline $\begin{array}{c}\text { Golongan } \\
\text { Darah }\end{array}$ & ANTI A & ANTI B \\
\hline $\mathrm{A}_{1}$ & 0.425 & 0.543 \\
\hline $\mathrm{A}_{2}$ & 0.426 & 0.560 \\
\hline $\mathrm{A}_{3}$ & 0.525 & 0.612 \\
\hline $\mathrm{A}_{4}$ & 0.566 & 0.729 \\
\hline $\mathrm{A}_{5}$ & 0.590 & 0.732 \\
\hline $\mathrm{AB}_{1}$ & 0.359 & 0.362 \\
\hline $\mathrm{AB}_{2}$ & 0.365 & 0.496 \\
\hline $\mathrm{AB}_{3}$ & 0.636 & 0.391 \\
\hline $\mathrm{AB}_{4}$ & 0.642 & 0.443 \\
\hline $\mathrm{AB}_{5}$ & 0.557 & 0.518 \\
\hline $\mathrm{O}_{1}$ & 0.656 & 0.546 \\
\hline $\mathrm{O}_{2}$ & 0.659 & 0.548 \\
\hline $\mathrm{O}_{3}$ & 0.707 & 0.549 \\
\hline $\mathrm{O}_{4}$ & 0.713 & 0.606 \\
\hline $\mathrm{O}_{5}$ & 0.758 & 0.610 \\
\hline $\mathrm{B}_{1}$ & 0.664 & 0.535 \\
\hline $\mathrm{B}_{2}$ & 0.666 & 0.561 \\
\hline $\mathrm{B}_{3}$ & 0.732 & 0.579 \\
\hline $\mathrm{B}_{4}$ & 0.686 & 0.581 \\
\hline $\mathrm{B}_{5}$ & 0.754 & 0.584 \\
\hline
\end{tabular}

Fuzzyfikasi adalah proses pemetaan data crisp menjadi bilangan Fuzzy yang berupa derajat keanggotaan (degree of membership). Dalam hal ini diperlukan himpunan fuzzy untuk data input serta himpunan fuzzy output sebagai hasil inferensi. Pada penelitian ini data input terdiri dari 2 (dua) linguistic value dan data output terbagi menjadi dua yaitu 5 (lima) linguistic value. Proses ekstraksi ciri yang sudah dilakukan dengan menggunakan metode Euclidean Distance dan Correlation Coefficient akan dijadikan crisp input yang akan disimpan kedalam variabel ED dan CC. Nilai Euclidean 
Distance yang digunakan dalam variabel input fuzzy adalah nilai maximum dari tiap golongan darah. Nilai Correlation Coefficient dan Correlation Coefficient yang digunakan dalam variabel input fuzzy adalah nilai average dari tiap golongan darah manusia. Untuk model Mamdani, operator Fuzzy yang digunakan adalah $A N D$ ( $\mathrm{min}$ ). aturan inferensi dinyatakan dalam Fuzzy Rule Based. Dengan dua input himpunan fuzzy dimana tipe himpunan fuzzy memiliki tiga linguistic variabel maka jumlah rules adalah $2^{3}=9$. Dengan linguistic variabel input Low, Medium, High dan linguistic variabel output Low (L), Low_Medium (LM), Medium (M), Medium_High (MH), High (H), maka Fuzzy Rule dinyatakan dengan tabel 5.

Tabel 5. Rule Base Dengan Output 5 Linguistic Value

\begin{tabular}{cccccc}
\hline \hline NO & ED & & CC & & Out \\
\hline 1 & LOW & AND & LOW & THEN & L \\
2 & LOW & AND & MED & THEN & LM \\
3 & LOW & AND & HIGH & THEN & M \\
4 & MED & AND & LOW & THEN & LM \\
5 & MED & AND & MED & THEN & M \\
6 & MED & AND & HIGH & THEN & MH \\
7 & HIGH & AND & LOW & THEN & M \\
8 & HIGH & AND & MED & THEN & MH \\
9 & HIGH & AND & HIGH & THEN & H
\end{tabular}

Untuk memeperoleh pola dari ciri pelatihan, maka dilakukan defuzzyfikasi yang ditunjukan pada gambar 12 .

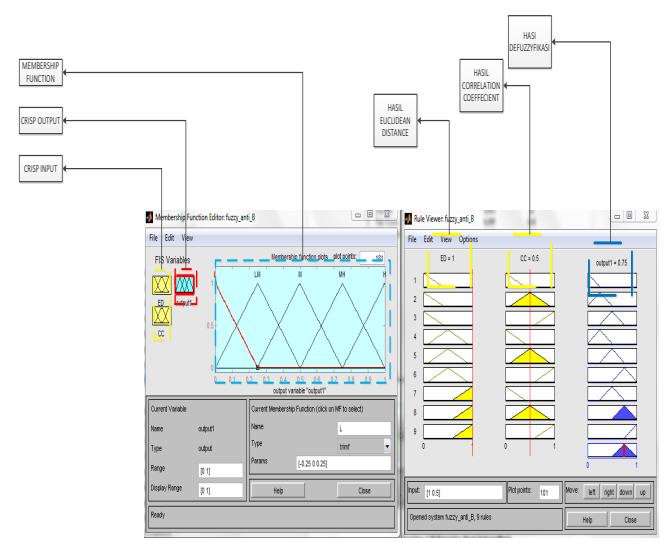

Gambar 12. Proses Defuzzyifikasi

Hasil dari defuzzyfikasi dikombinasikan dengan tabel penggolongan darah sebagai pembuktian apakah hasil FIS sesuai dengan teori penggolongan darah $\mathrm{ABO}$ seperti yang ditampilkan pada tabel 6 .
Tabel 6. Penggolongan darah Berdasarkan Serum Anti A dan Anti B

Golongan Darah Anti A Anti B

\begin{tabular}{ccc}
\hline $\mathrm{A}$ & + & - \\
\hline $\mathrm{B}$ & - & + \\
\hline $\mathrm{AB}$ & + & + \\
\hline $\mathrm{O}$ & - & - \\
\hline
\end{tabular}

Tahap berikut adalah membangun tabel kebenaran berdasarkan hasil pelatihan yang dibandingkan dengan tabel sistem A,B,O golongan darah yang hasil nya bisa dilihat pada tabel 7.

Tabel 7. Linguistic Value Kebenaran Pola Latih Golongan Darah

\begin{tabular}{ccc}
\hline $\begin{array}{c}\text { Golongan } \\
\text { Darah }\end{array}$ & ANTI A & ANTI B \\
\hline $\mathrm{A}$ & LM & LM \\
\hline $\mathrm{B}$ & $\mathrm{M}$ & $\mathrm{M}$ \\
\hline $\mathrm{AB}$ & $\mathrm{M}$ & LM \\
\hline $\mathrm{O}$ & LM & $\mathrm{M}$ \\
\hline
\end{tabular}

Kemudian dengan cara yang sama pada proses fuzzy inference system untuk semua data uji, maka dapa dibangun tabel pengujian seperti ditunjukan pada tabel 8 .

Tabel 8. Uji Verifikasi

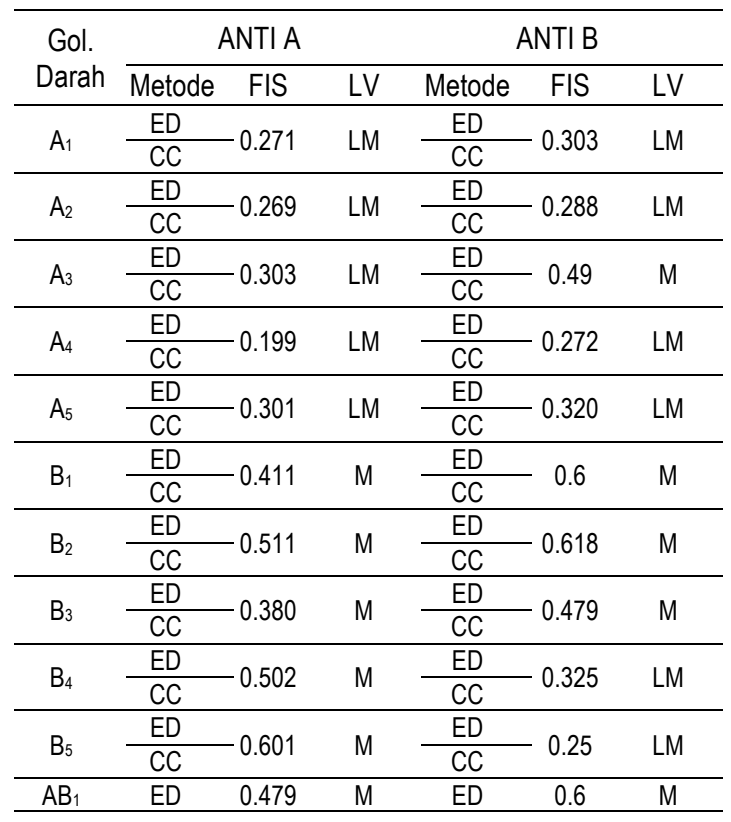




\begin{tabular}{|c|c|c|c|c|c|}
\hline & $\mathrm{CC}$ & & & CC & \\
\hline \multirow{2}{*}{$\mathrm{AB}_{2}$} & ED & \multirow{2}{*}{0.3} & \multirow{2}{*}{ LM } & ED & \multirow{2}{*}{ M } \\
\hline & $\mathrm{CC}$ & & & CC & \\
\hline \multirow{2}{*}{$\mathrm{AB}_{3}$} & ED & \multirow{2}{*}{0.45} & \multirow{2}{*}{$\mathrm{M}$} & ED & \multirow{2}{*}{$\mathrm{M}$} \\
\hline & $\mathrm{CC}$ & & & CC & \\
\hline \multirow{2}{*}{$\mathrm{AB}_{4}$} & ED & \multirow{2}{*}{0.6} & \multirow{2}{*}{$\mathrm{M}$} & ED & \multirow{2}{*}{ LM } \\
\hline & $\mathrm{CC}$ & & & $\mathrm{CC}$ & \\
\hline \multirow{2}{*}{$\mathrm{AB}_{5}$} & ED & \multirow{2}{*}{0.5} & \multirow{2}{*}{$\mathrm{M}$} & ED & \multirow{2}{*}{ LM } \\
\hline & $\mathrm{CC}$ & & & $\mathrm{CC}$ & \\
\hline \multirow{2}{*}{$\mathrm{O}_{1}$} & ED & \multirow{2}{*}{0.275} & \multirow{2}{*}{ LM } & ED & \multirow{2}{*}{ M } \\
\hline & $\mathrm{CC}$ & & & $\mathrm{CC}$ & \\
\hline \multirow{2}{*}{$\mathrm{O}_{2}$} & ED & \multirow{2}{*}{0.55} & \multirow{2}{*}{$\mathrm{M}$} & ED & \multirow{2}{*}{$\mathrm{M}$} \\
\hline & $\mathrm{CC}$ & & & $\mathrm{CC}$ & \\
\hline \multirow{2}{*}{$\mathrm{O}_{3}$} & ED & \multirow{2}{*}{0.275} & \multirow{2}{*}{ LM } & ED & \multirow{2}{*}{ LM } \\
\hline & $\mathrm{CC}$ & & & $\mathrm{CC}$ & \\
\hline \multirow{2}{*}{$\mathrm{O}_{4}$} & ED & \multirow{2}{*}{0.199} & \multirow{2}{*}{ LM } & ED & \multirow[b]{2}{*}{ LM } \\
\hline & $\mathrm{CC}$ & & & CC & \\
\hline \multirow{2}{*}{$\mathrm{O}_{5}$} & ED & \multirow{2}{*}{0.411} & \multirow{2}{*}{$\mathrm{M}$} & ED & \multirow[b]{2}{*}{$M$} \\
\hline & CC & & & CC & \\
\hline
\end{tabular}

\section{Uji Performansi}

Unjuk kerja suatu sistem pengenalan pola dapat diukur berdasarkan nilai kesalahan yang terjadi dan dapat pula diukur dari seberapa besar tingkat kesuksesan pengenalan pola. Unjuk kerja pada model klasifikasi dapat dilihat dengan dua model kesalahan yakni False Acceptance Rate (FAR ) atau rasio kesalahan penerimaan dan False Rejection Rate $(F R R)$ atau rasio kesalahan penolakan. Dalam unjuk kerja model klasifikasi maka perlu dilakukan perhitungan untuk pencarian True Positive Rate (TPR), False Positive Rate(FPR), dan True Negative Rate (TNR). yang dijabarkan sebagai berikut [8]

- TPR juga biasa disebut dengan sensivity, atau rasio ketepatan, rumus nya adalah match valid image selanjutnya disebut True Positive (TP) dibagi jumlah valid image (P)

$$
\mathrm{TPR}=\frac{\mathrm{TP}}{\mathrm{P}}
$$

- FPR juga bisa disebut alarm kesalahan atau rasio ketidak tepatan, rumus nya adalah unmatch valid image selanjutnya disebut False Positive (FP) dibagi jumlah forgery image $(\mathrm{N})$

$$
\mathrm{FPR}=\frac{\mathrm{FP}}{\mathrm{N}}
$$

- TNR juga bisa disebut specificity, rumusnya adalah match forgery image selanjutnya disebut True Negative (TN) dibagi jumlah forgery image $(\mathrm{N})$.

$$
\mathrm{TNR}=\frac{\mathrm{TN}}{\mathrm{N}} \quad » \quad \mathrm{TNR}=1-\mathrm{FPR}
$$

Selanjutnya adalah memperoleh FAR dan FRR, serta Accuracy yang dijelaskan berikut :
- False Acceptance Rate adalah nilai dari False Positive Rate, dinyatakan dengan persamaan seperti berikut:

$$
\mathrm{FAR}=\mathrm{FPR}
$$

- False Rejectance Rate adalah nilai dari False Negative Rate, persamaan nya adalah

$$
\mathrm{FRR}=\frac{F N}{P} \text { atau } \rightarrow 1-T P R
$$

- Accuracy yang selanjutnya disebut Acc, adalah prosentase ketepatan keberhasilan total pengujian terhadap prototype ciri, persamaan yang menyatakan nya adalah :

$$
\mathrm{Acc}=\frac{(\mathrm{TP}+\mathrm{TN})}{(\mathrm{P}+\mathrm{N})} \times 100 \%
$$

\begin{tabular}{|c|c|c|c|c|c|}
\hline \multirow{2}{*}{$\begin{array}{c}\text { Gol. } \\
\text { Darah }\end{array}$} & \multicolumn{5}{|c|}{$\mathrm{A}$} \\
\hline & Sampel & $\mathrm{TP}$ & FP & $\mathrm{TN}$ & $\mathrm{FN}$ \\
\hline \multirow{5}{*}{ A } & 1 & 1 & 0 & & \\
\hline & 2 & 1 & 0 & & \\
\hline & 3 & 0 & 1 & & \\
\hline & 4 & 1 & 0 & & \\
\hline & 5 & 1 & 0 & & \\
\hline \multirow{5}{*}{ B } & 1 & & & 0 & 1 \\
\hline & 2 & & & 0 & 1 \\
\hline & 3 & & & 0 & 1 \\
\hline & 4 & & & 0 & 1 \\
\hline & 5 & & & 0 & 1 \\
\hline \multirow{5}{*}{$\mathrm{AB}$} & 1 & & & 0 & 1 \\
\hline & 2 & & & 0 & 1 \\
\hline & 3 & & & 1 & 0 \\
\hline & 4 & & & 0 & 1 \\
\hline & 5 & & & 0 & 1 \\
\hline \multirow{5}{*}{$\mathrm{O}$} & 1 & & & 0 & 1 \\
\hline & 2 & & & 0 & 1 \\
\hline & 3 & & & 0 & 1 \\
\hline & 4 & & & 0 & 1 \\
\hline & 5 & & & 0 & 1 \\
\hline Total & & 4 & 1 & 1 & 14 \\
\hline $\mathrm{P}$ & & & 5 & & \\
\hline $\mathrm{N}$ & & & 15 & & \\
\hline
\end{tabular}

Pada percobaan pengujian, maka diperoleh nilai FAR, FRR dan Acc yang ditunjukkan dalam satu contoh tabel dibawah ini :

Tabel 8. Unjuk Kerja Golongan Darah A

Begitupula pengujian terhadap golongan darah $\mathrm{B}, \mathrm{AB}$ dan $\mathrm{O}$ dengan memperhatikan dari tabel 7 terhadap tabel 6.dapat diperoleh nilai dari $\mathrm{P}_{\mathrm{B}}, \mathrm{P}_{\mathrm{AB}}, \mathrm{P}_{\mathrm{O}}$ begitu pula untuk nilai $\mathrm{N}, \mathrm{TP}, \mathrm{TN}$, FP, dan FN. Untuk mendapatkan hasil accuracy yang dilakukan adalah menghitung FPR dan FRR. Dari proses verifikasi yang dilakukan dalam penelitian ini sehingga didapatkan

$$
\begin{aligned}
\mathrm{P}_{\text {total }} & =\mathrm{P}_{\mathrm{A}}+\mathrm{P}_{\mathrm{B}}+\mathrm{P}_{\mathrm{AB}}+\mathrm{P}_{\mathrm{O}} \\
& =5+5+5+5 \\
& =20 \\
\mathrm{~N}_{\text {total }} & =\mathrm{N}_{\mathrm{A}}+\mathrm{N}_{\mathrm{B}}+\mathrm{N}_{\mathrm{AB}}+\mathrm{N}_{\mathrm{O}}
\end{aligned}
$$




$$
\begin{aligned}
& =15+15+15+15 \\
& =60 \\
& =\mathrm{TP}_{\mathrm{A}}+\mathrm{TP}_{\mathrm{B}}+\mathrm{TP}_{\mathrm{AB}}+\mathrm{TP}_{\mathrm{O}} \\
& =4+4+4+3 \\
& =15 \\
\mathrm{FP}_{\text {total }} & =\mathrm{FP}_{\mathrm{A}}+\mathrm{FP}_{\mathrm{B}}+\mathrm{FP}_{\mathrm{AB}}+\mathrm{FP}_{\mathrm{O}} \\
& =1+1+1+2 \\
& =5 \\
\mathrm{TN}_{\text {total }} & =\mathrm{TN}_{\mathrm{A}}+\mathrm{TN}_{\mathrm{B}}+\mathrm{TN}_{\mathrm{AB}}+\mathrm{TN}_{\mathrm{O}} \\
& =14+11+13+13 \\
& =51 \\
\mathrm{FN}_{\text {total }} & =\mathrm{FN} \\
& =1+4+\mathrm{FN}_{\mathrm{B}}+\mathrm{FN}_{\mathrm{AB}}+\mathrm{FN}_{\mathrm{O}} \\
& =9
\end{aligned}
$$

Maka performansi dari verifikasi 20 sampel terhadap data latih diperoleh FAR sebesar $8 \%$, FRR sebesar 45\%, dengan tingkat akurasi sebesar $83 \%$

\section{KESIMPULAN}

Sel darah yang dirupakan dalam bentuk citra dijital walau memiliki karakteristik yang khas apabila dikenakan serum anti A dan anti B pada penelitian ini berhasil dibangun sebuah pola hasil pelatihan dengan menggunakan kombinasi ekstraksi ciri metode euclidean distance dan correlation coefficient. Pola ciri pelatihan terbentuk sesuai gambar 10 dan 11, yang dipurwarupakan dalam tabel 6 . Pola pelatihan tersebut kemudian berhasil diuji dengan 20 sampling data yang bervariatif dengan menggunakan fuzzy inference system dengan output lima (5) linguistic value dimana rentang output berada di low medium dan medium. Uji unjuk kerja pada percobaan ini menghasilkan performance FAR 08\%, FRR $45 \%$ dan Akurasi $83 \%$ yang dalam hal ini klasifikasi golongan darah yang berhasil di verifikasi dinyatakan cukup handal karena akurasi diatas $70 \%$

\section{SARAN}

Penelitian ini masih menggunakan batasan kualitatif dalam proses akuisisi objek sehingga performansi uji verifikasi cukup akurat, tentunya jika batasan tersebut dihapuskan sehingga menjadi real time akuisisi maka perlu dilakukan perubahan metode ekstraksi ciri dan penggunaan jenis fuzzy inference system yang lebih tepat agar akurasi verifikasi mampu dipertahankan di level $70 \%$. Objek dengan tipe citra true color menjadi harapan peneliti untuk dapat dikembangkan di penelitian selanjutnya.

\section{UCAPAN TERIMA KASIH}

Peneliti mengucapkan terimaksih kepada pihak Laboratorium Rumah Sakit Pupuk Kaltim Siaga Ramania Samarinda sebagai penyedia sumber data penelitian ini. Serta Laboratorium dan Modern Computing Research Center Jurusan Teknologi Informasi Politeknik Negeri Samarinda yang menjadi tempat berkarya peneliti.

\section{DAFTAR PUSTAKA}

[1] Fitryadi, K., Sutikno,"Pengenalan Jenis Golongan Darah Menggunakan Jaringan Syaraf Tiruan Perceptron",Jurnal Masyarakat Informatika, Vol.7 No.1 (2016) : 01-10

[2] Oktari, A., Silvia,N.D., "Pemeriksaan Golongan Darah Sistem ABO Metode Slide dengan Reagen Serum Golongan Darah A, B, O", Jurnal Teknologi Laboratorium, ISSN :2338-5634, Vol.5 No.2 (September 2016).

[3] Putra, D,"Sistem Verifikasi Menggunakan Garis-Garis Telapak Tangan",Majalah Ilmiah Teknologi Elektro, EISSN : 25032372 Vol.6 No.2 (2007) : 46-51

[4] Putra, A.B.W., Putri, M.H.H, "Verifikasi Pola Tanda Tangan Dosen TI Polnes Menggunakan Fuzzy Rule Base",Jurnal Smartics, Vol. 1,No. 1 (2015) : 06-13

[5] Putra, A.B.W, Rihartanto, Subkhiana, E. "Ekstraksi Ciri Entropy Untuk Pengenalan Pola Wajah Menggunakan Fuzzy Rule Base”. Jurnal Smartics, Vol.2 No.2 (2016) : 01-08

[6] Gonzales Re, Woods Re, Digital Image Processing Edisi $\mathrm{Ke}$ 2, New Jersey : Prentince Hall, Inc, (2002)

[7] Putra, D., Pengolahan Citra Digital : Andi Offset, Yogyakarta, (2010)

[8] Putra, A.BW., Pramono, S.H, Naba, A. "Rancang Bangun Prototype Ciri Citra Kulit Luar Kayu Menggunakan Metode VCG”. Jurnal EECCIS Vol.8 No.1 (2014) $: 19-26$ 